DOI: https://doi.org/10.15407/techned2018.04 $: 118$

\title{
NUMERICAL INVESTIGATION OF THE ELECTROMAGNETIC STIRRING SYSTEM OF LIQUID METAL IN SKULL CRUSIBLE WITH ELECTRON-BEAM MELTING
}

Journal

Publisher

ISSN

Issue

Pages
Tekhnichna elektrodynamika

Institute of Electrodynamics National Academy of Science of Ukraine 1607-7970 (print), 2218-1903 (online)

No 4, 2018 (July/August)

$118-126$

\section{Authors}

Y.M. Goryslavets ${ }^{1 \star}$, S.V. Ladokhin ${ }^{2}$, O.I. Glukhenkyi ${ }^{1 * \star}$, T.V. Lapshuk ${ }^{2}$, O.I. Bondar ${ }^{1}$, E.O. Drozd

1 - Institute of Electrodynamics National Academy of Sciences of Ukraine,

pr. Peremohy, 56, Kyiv, 03057, Ukraine,

e-mail: gai56@ied.org.ua

2 - Physico-Technological Institute of Metals and Alloys of the National Academy of Sciences of Ukraine,

Vernadsky blvd., 34/1, Kyiv, 03142, Ukraine,

e-mail: e_luch@ptima.kiev.ua

* ORCID ID : http://orcid.org/0000-0003-1668-4972

** ORCID ID : http://orcid.org/0000-0001-5053-5677

\section{Abstract}

The brief information on the history and peculiarities of electron-beam skull melting technology 
of refractory metals and alloys is given. Its advantages and disadvantages are formulated. One of the main directions of further development is the maximum amount of melt in the skull crucible increasing. The necessity of mathematical modeling of multifunctional processes for the rational choice of the design of a skull crucible with electromagnetic stirring system, which provides obtaining up to $150 \mathrm{~kg}$ of titanium melt in one melting process, is substantiated. In particular, the question of choosing the design and operating modes of the electromagnetic stirring system with an emphasis on the peculiarities of its work at the initial stage of the accumulation of the melt are considered. The methodology of numerical three-dimensional modeling of the electromagnetic field and hydrodynamics in the system "inductor - scull crucible" is given. An electromagnetic problem is formulated relative to the vector magnetic and scalar electric potentials, hydrodynamic - in the form of Navier-Stokes equations using the Low Reynolds $k-\varepsilon$ turbulence model. Among the factors that determine the effectiveness of an electromagnetic stirrer we considered: the number of coils of the inductor, the angle of phase shift between the currents of the coils, the direction of the travelling magnetic field, the frequency of the power supply. The electromagnetic and hydrodynamic problems were calculated for the five positions of the interface between melt and skull which correspond to the sequential stages of the melting process with the gradually increased melt volume in the crucible. The inductors with two, three, and six coils were considered. When comparing variants, the average speed of motion in the melt volume was taken as the criterion for the stirring efficiency. The results of computational research are presented, the algorithm of electromagnetic stirring system operation is proposed. References 9, figures 8.

Key words: electron-beam melting, skull crucible, electromagnetic stirring system, mathematical modeling of electromagnetic and hydrodynamic processes.

Received: 01.11.2017

Accepted: 04.12.2017

Published: 


\section{References}

1. Gladkov A.S., Levitsky N.I., Chernyavsky V.B. Features of melting of complex alloys on the basis of titanium and zirconium in electron-beam casting skull installations. Proc. Intern. Conf. Ti-2008 in the CIS

St. Petersburg, May 18-21, 2008. Pp. 50-53. (Rus)

2. Glukhenkyi A.I., Goryslavets Y.M., Bondar A.I., Ladokhin S.V., Lapshuk T.V., Drozd E.A. The modeling of electron-beam melting of titanium in skull crucible. Protsesy littia. 2017. No 2. Pp. 30-38. (Rus)

3. Glukhenkyi A.I., Goryslavets Y.M., Bondar A.I., Ladokhin S.V., Lapshuk T.V., Drozd E.A. Design of skull crucibles of high-capacity for electron-beam melting of titanium. Protsesy littia. 2017. No 4. Pp. 58-65. (Rus)

4. Podoltsev A.D., Kucheriva I.N., Ladokhin S.V. Analysis of MHD processes during electromagnetic stirring of molten metal in a sectional conductive crystallizer. Proc. $3^{\text {rd }}$ Intern. Conf. Inconventional Electromechanical and Electrical System

, Alushta, the Crimea, Ukraine, September 19-21, 1997. Pp. 1193-1200. (Rus)

5. Ulianov V.L. Electron-beam skull melting upon receiving of shaped castings. Liteinoe proizvodstvo

1972. No 10. Pp. 13-15. (Rus)

6. Schiller Z., Gaizig W., Panzer Z. Electron-beam technology. Moskva: Enerhiia, 1980. 528 p. (Rus)

7. Electron-beam melting in foundry. Kiev: Stal, 2007. 626 p. (Rus)

8. Frei W. Which Turbulence Model Should I Choose for My CFD Application? URL: https://w ww.comsol.com/blogs/which-turbulence-model-should-choose-cfd-application

(Accessed at 28.09.2017)

9. Westerberg K.W., Meier T.C., McClelland M.A. Analysis of the E-Beam Evaporation of Titanium and Ti-6Al-4V. Proc. Conf. Electron Beam Melting and Refining - State of the Art 1997 , Bakish Materials Corp., Englewood, NJ. P. 208-221.

\section{$\underline{\text { PDF }}$}

